\title{
IN VITRO EVALUATION OF NEONATAL HUMAN IMMUNITY AGAINST THE PIG
}

$\mathrm{He} \mathrm{Xu}, \mathrm{MD}$

Soji F. Oluwole, MD

Niloo M. Edwards, MD

Jonathan M. Chen, MD

Yoshifumi Naka, MD

Eugene Kim, BS

Robert E. Michler, MD
The critical shortage of organ donors has greatly limited the number of clinical allotransplantations. This is particularly true for neonatal patients, for whom xenotransplantation could provide an alternative therapeutic option to allotransplantation. The role of neonatal infant immunity in xenotransplantation is not, however, clearly understood. We examined both the proliferative responses of human neonatal lymphocytes to pig aortic endothelial cells and serum levels of neonatal natural antipig xenoantibody. Neonatal human lymphocytes and serum were isolated from umbilical cord blood. Adult human lymphocytes and serum were used as controls. A one-way xenogeneic mixed lymphocyte-endothelial cell reaction was performed, and lymphocyte proliferation was measured by tritiated thymidine uptake. Neonatal human lymphocytes recognized and proliferated in response to pig aortic endothelial cells (mean $63,926 \pm 26,054$ counts per minute). The level of xenogeneic mixed Iymphocyte-endothelial cell reaction of neonatal lymphocytes was significantly lower $(\mathrm{p}<0.004)$ than that of adult human lymphocytes (mean $122,444 \pm 33,132$ counts per minute). An enzyme-linked immunosorbent assay was performed to determine the binding of natural immunoglobulin $M$ and $G$ antibodies to pig endothelial cells. Whole-cell enzyme-linked immunosorbent assay demonstrated neonatal human serum to contain very low binding levels of natural antipig immunoglobulin $M$ xenoantibody compared with adult serum. Like adult serum, neonatal human serum contained natural antipig immunoglobulin G xenoantibody. Neonatal serum was not cytotoxic to pig endothelial cells, suggesting that immunoglobulin $G$ was not the predominant xenoreactive antibody. To assess whether neonatal pig endothelial cells also expressed xenoantigens, adult and neonatal cultured pig endothelial cells were examined by enzyme-linked immunosorbent assay with adult human serum. Adult human natural immunoglobulin $M$ xenoantibody recognized not only adult pig endothelial cell xenoantigens but also neonatal pig endothelial cell xenoantigens. The binding levels of adult natural antipig immunoglobulin $\mathrm{M}$ xenoantibodies to adult and neonatal pig endothelial cells were similar, suggesting that neonatal pig aortic endothelial cells express xenoantigens. The findings of low binding levels of cytotoxic antipig immunoglobulin $M$ xenoantibody and low levels of lymphocyte xenoreactivity to pig endothelial cells in human neonates suggests that pig organs may eventually be a suitable source of xenografts for human neonates. (J Thorac Cardiovasc Surg 1996;111:920-9)
From the Cardiac Transplantation Research Laboratory, Department of Surgery, Columbia University College of Physicians and Surgeons and the Cardiac Transplant Service, Division of Cardiothoracic Surgery, Columbia Presbyterian Medical Center, New York, N.Y.

Presented in part at the Sixty-seventh Scientific Sessions of the American Heart Association, Dallas, Tex., Nov. 14-17, 1994.

Received for publication Dec. 22, 1994; accepted for publication July 3, 1995.
Address for reprints: Robert E. Michler, MD, Director, Cardiac Transplant Service, and Director, Cardiac Transplantation Research Laboratory, Division of Cardiothoracic Surgery, Columbia Presbyterian Medical Center, 177 Fort Washington Ave, Milstein Hospital Building, Room 7435, New York, NY 10032.

Copyright (C) 1996 by Mosby-Year Book, Inc.

$0022-5223 / 96 \$ 5.00+0 \quad \mathbf{1 2} / \mathbf{1} / \mathbf{6 7 5 0 4}$ 
Volume 111, Number 5

A lthough cardiac allotransplantation has become the therapy of choice for patients with end-stage heart disease, the number of patients on the waiting list for heart transplantation continues to grow. The shortage of donor organs has therefore become the major barrier to the future growth of clinical cardiac allotransplantation., 2 This predicament is particularly true for neonates, for whom there are no alternatives to cardiac transplantation such as mechanical assist devices. For this reason, xenogeneic transplantation has been considered as a potential solution to the critical shortage of donor organs for the neonatal recipient population.

Pigs represent an attractive choice as xenodonors because they are readily available, are relatively easy to breed, represent low risk of epizootic disease transmission, and are available in all sizes appropriate for use as donors for human beings. Although pig cardiac endothelium expresses $\mathrm{ABO}$ antigens, ${ }^{3}$ the immunologic significance of this expression is probably small. The clinical application of pig xenotransplantation is currently, however, limited by hyperacute rejection, which occurs within minutes to hours. ${ }^{4.5}$ This immunologic reaction is believed to be mediated primarily by the binding of natural antipig xenoantibody to the endothelium of the xenograft, with subsequent activation of the complement cascade and vascular endothelial cell (EC) injury. ${ }^{6}$ Such an injury results in disruption of the vascular endothelium and microcirculation, interstitial hemorrhage, edema, vasospasm, adhesion of platelets and fibrin, thrombus formation, and myocardial cell ischemic necrosis. ${ }^{7-9}$ In experimental cardiac xenotransplantation, the removal of natural antipig xenoantibody by donor organ hemoperfusion, ${ }^{10}$ plasma exchange, ${ }^{11}$ plasmapheresis, $^{12}$ and inhibition of complement ${ }^{13}$ has resulted in modest prolongation of xenograft survival. There have been no in vivo opportunities to examine the role of cell-mediated immunity in the pathogenesis of distantly related xenotransplantation rejection because of the rapid graft loss seen with hyperacute rejection. As a surrogate for this in vivo experiment, this in vitro study was undertaken to examine whether neonatal human lymphocytes can recognize and proliferate in response to pig EC xenoantigens and whether neonatal human serum contains natural antipig xenoantibodies. Institutional Review Board ap- proval (IRB \#0116) by both institutions was obtained for this study.

\section{Material and methods}

Preparation of serum samples. Pooled adult human blood samples were obtained from healthy volunteers from our laboratory $(n=10)$, and neonatal human blood samples were collected from the umbilical veins of normal term infants $(n=10)$. The blood was centrifuged at $800 \mathrm{~g}$ for 20 minutes, and the serum samples were pooled and heat treated for 30 minutes at $56^{\circ} \mathrm{C}$ to inactivate complement. The aliquots of these serum samples were then stored at $-80^{\circ} \mathrm{C}$.

Preparation of human peripheral blood leukocytes (PBLs). Heparinized adult human peripheral blood was obtained from healthy volunteers from our laboratory $(n=4)$, and heparinized neonatal human peripheral blood was collected from the umbilical vein of normal term infants $(n=10)$. The blood samples were layered on top of Isopaque-Ficoll (Gallard-Schlesinger Industries, Inc., New York, N.Y.) and centrifuged. The PBLs were harvested and washed twice with Hank's medium (Life Technologies, Inc., Gaithersburg, Md.). The viability of PBLs was measured by trypan blue dye exclusion and was consistently greater than $98 \%$. The cells were then suspended in RPMI-1640 (Life Technologies).

Preparation of target cells. Pig aortic ECs were isolated from both adult and neonatal pig aortas with collagenase. These cells were then cultured in Dulbecco's modified Eagle medium (Life Technologies) containing $10 \%$ fetal calf serum (Life Technologies) as described by Rosiers, Nees, and Gerlach. ${ }^{14}$ Subculture of these cells was performed in Dulbecco's modified Eagle medium containing $10 \%$ fetal calf serum.

Immunoassay. A xenogeneic mixed lymphocyte-EC reaction assay (xMLER) was performed to determine the immunoreactivity of both adult and neonatal human PBLs to cultured pig aortic ECs. A whole-cell enzyme-linked immunosorbent assay (ELISA) was performed to determine the binding levels of human natural antipig xenoantibodies. Cytotoxicity of these serum samples to cultured pig aortic ECs was measured with a 3-(4,5-dimethylthiazoyl-2-y) 2,5 diphenyl-tetrazolium bromide (MTT) assay.

xMLER. Cultured pig aortic ECs were transferred to separate 96-well plates and irradiated at 3.75 Gy for 5 minutes. These irradiated pig ECs were used as stimulator cells and were cultured with either adult human PBLs or neonatal human PBLs in RPMI-1640 medium (Life Technologies) supplemented with $10 \%$ complement-inactivated human serum and penicillin (Life Technologies) at $37^{\circ} \mathrm{C}$ in $5 \%$ carbon dioxide for 6 days. On the sixth day, the cells were pulse labeled with tritiated thymidine at 1 $\mu \mathrm{Ci} /$ well for 8 hours and then harvested with a cell harvester. Tritiated thymidine incorporation was measured with a $\beta$-liquid scintillation counter. Adult human PBLs were tested at $5 \times 10^{4}$ cells/well, $1 \times 10^{5}$ cells/well, and $2 \times 10^{5}$ cells/well. Neonatal human PBLs were tested at $2 \times 10^{5}$ cells/well. Responder cells alone and stimulator cells alone were used as negative controls. The results were expressed as counts per minute of triplicate samples. 


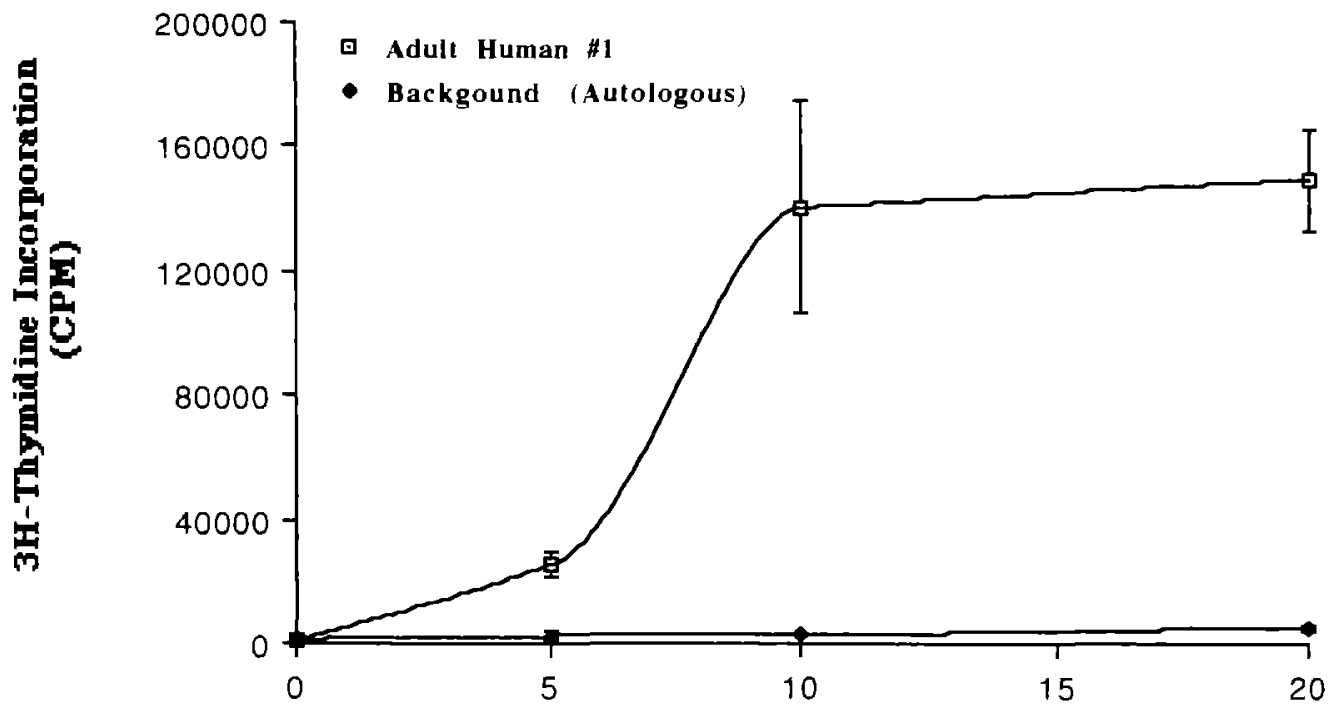

A

Number of Responders ( $\times 10^{4}$ cells/well)
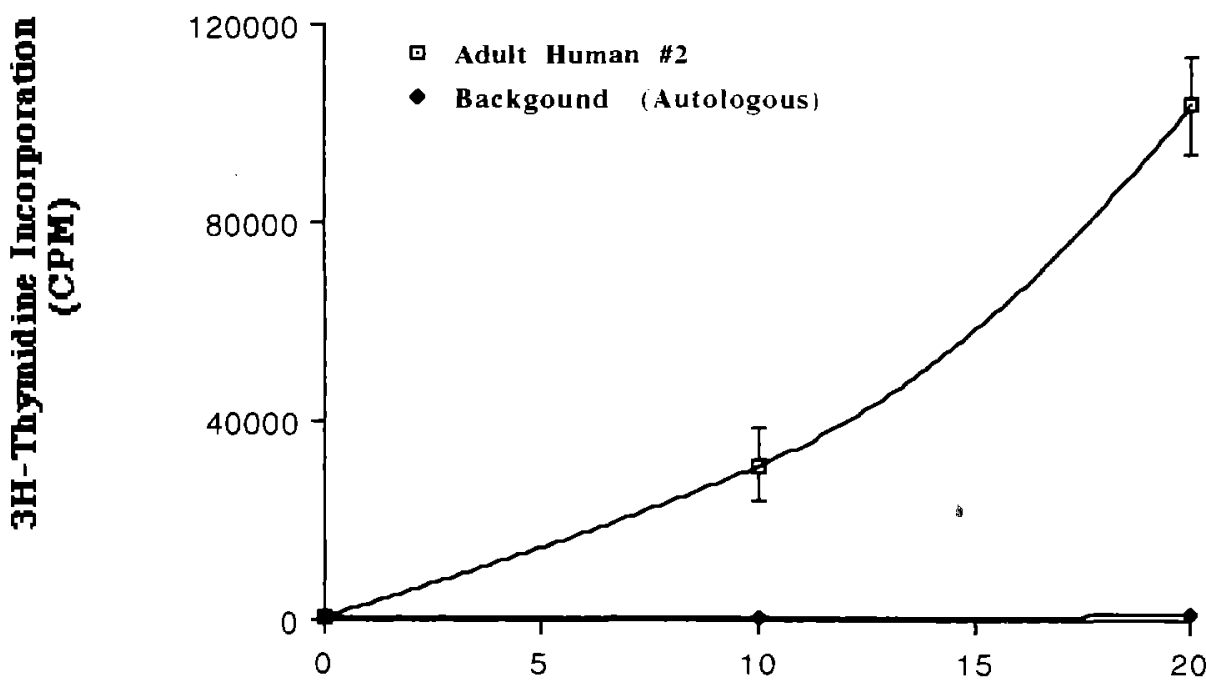

B

Number of Responders ( $x 1^{4}$ cells/well)

Fig. 1. Determination of appropriate number of responder cells for proliferative response to cultured pig ECs in xMLER. A, The proliferative response of adult human subject 1's PBLs to pig ECs was detected at $5 \times 10^{4}$ cells/well and reached extremely high levels at $20 \times 10^{4}$ cells/well. B, The XMLER showed an extremely strong proliferation from adult human subject 2's PBLs in response to pig ECs at $20 \times 10^{4}$ cells/well.

Cellular ELISA. Binding levels of natural antipig xenoantibodies to cultured pig aortic ECs was measured by ELISA, as previously described by Platt and colleagues. ${ }^{15}$ Cultured pig aortic ECs were transferred to separate flat-bottom 96-well plates and grown to confluence. These cultured pig EC monolayers were fixed with $0.01 \%$ glu- taraldehyde for 5 minutes and then washed three times with cold $\left(40^{\circ} \mathrm{C}\right)$ phosphate-buffered saline solution (PBS). After the final wash, the cells were incubated for 60 minutes with $1 \%$ bovine serum albumin (Sigma Chemical Co., St. Louis, Mo.) in PBS at $40^{\circ} \mathrm{C}$ to block the nonspecific binding of antibodies. 


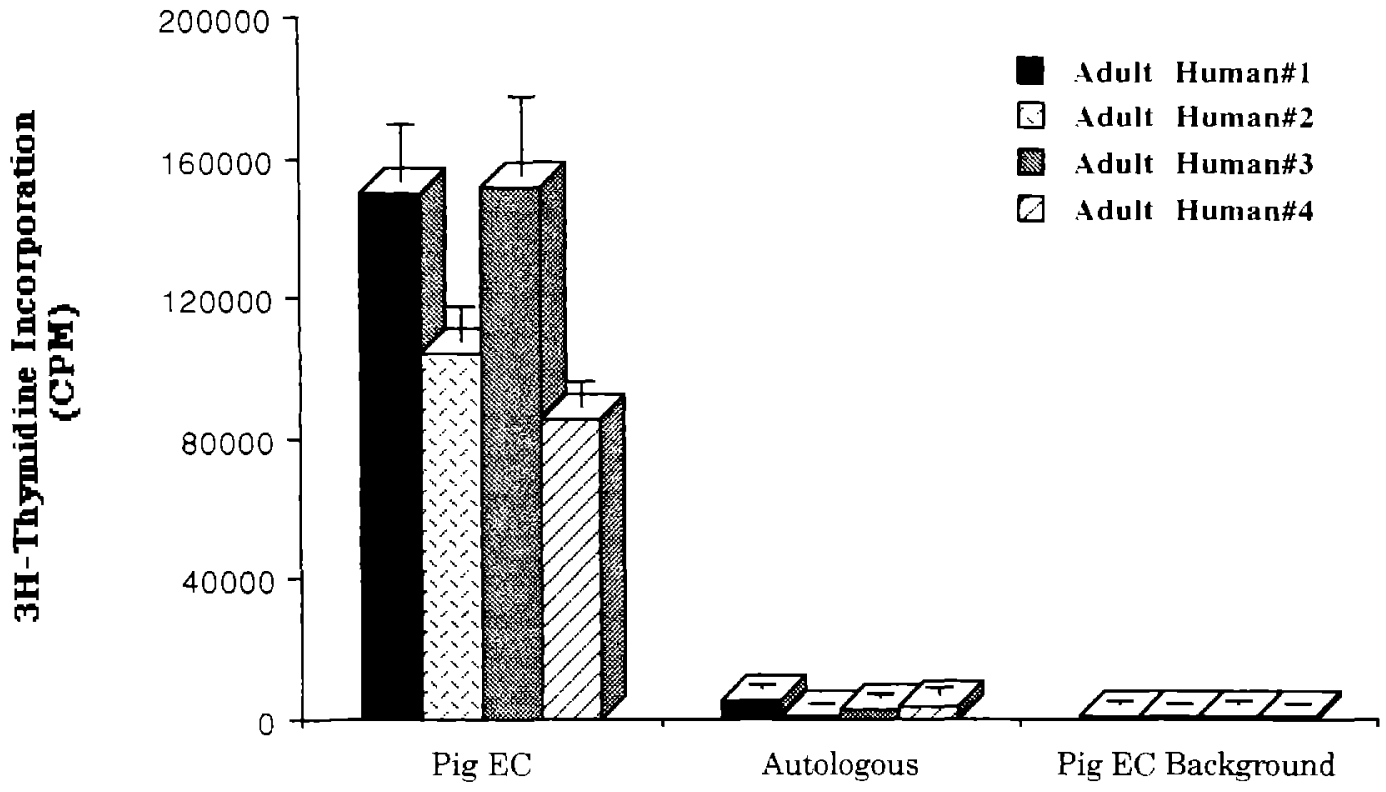

\section{Stimulating Cell}

Fig. 2. The xMLER demonstrates proliferation of human adult lymphocytes in response to cultured pig ECs $\left(2 \times 10^{5}\right.$ lymphocytes/well).

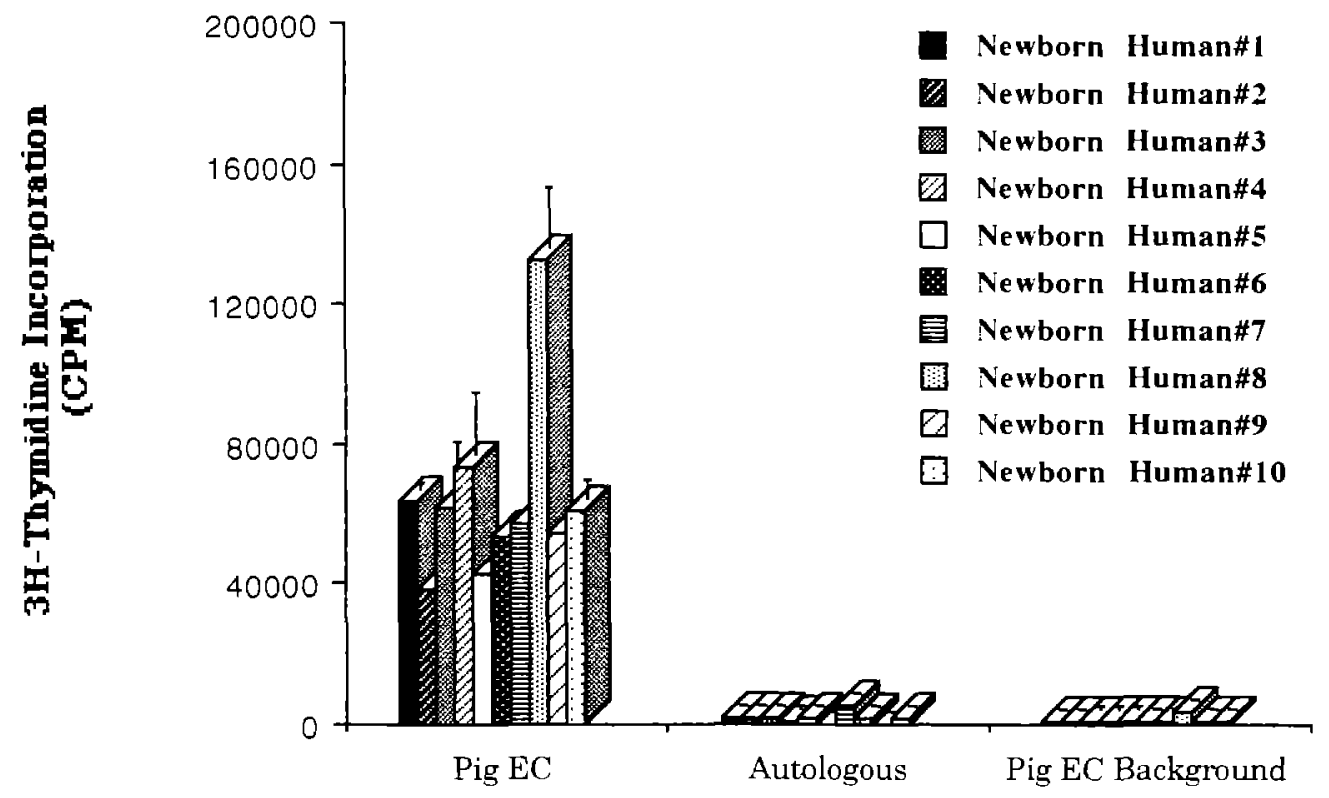

\section{Stimulating Cell}

Fig. 3. The xMLER demonstrates proliferation of human neonatal lymphocytes in response to cultured pig ECs $\left(2 \times 10^{5}\right.$ lymphocytes/well). 


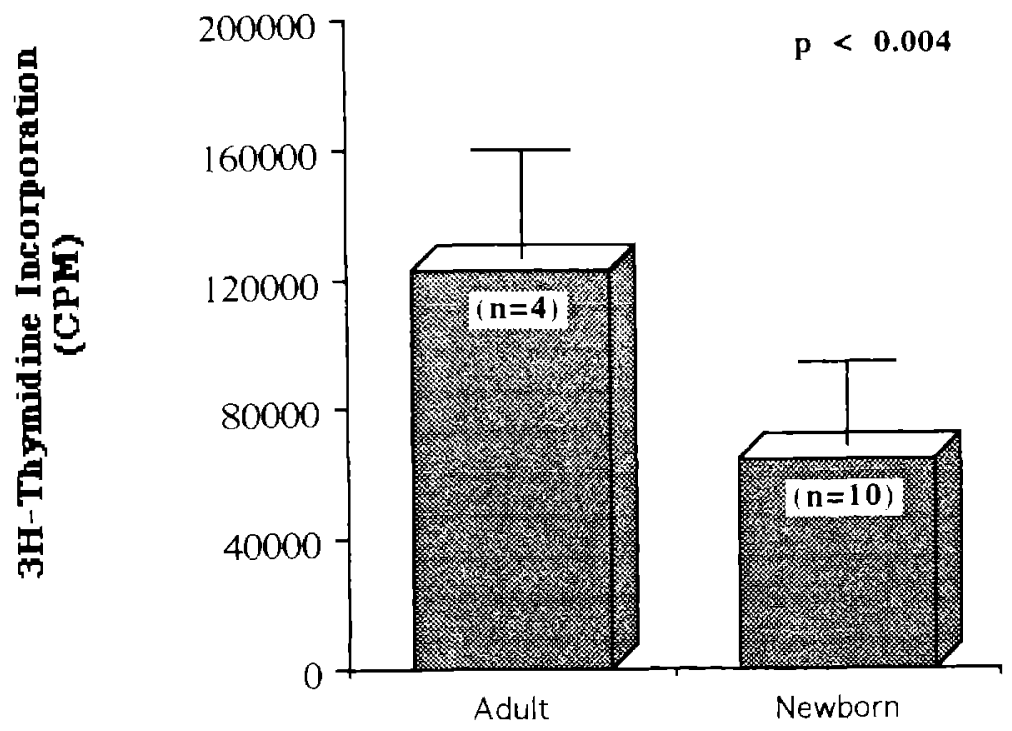

Human PBL

Fig. 4. Comparison of immune responses of PBLs $\left(2 \times 10^{5}\right.$ cells/well $)$ from human adults $(n=4)$ and neonates $(n=10)$ in response to cultured pig ECs in xMLER. Human neonates demonstrate lower levels of PBL proliferation than seen in human adults $(p<0.004)$.

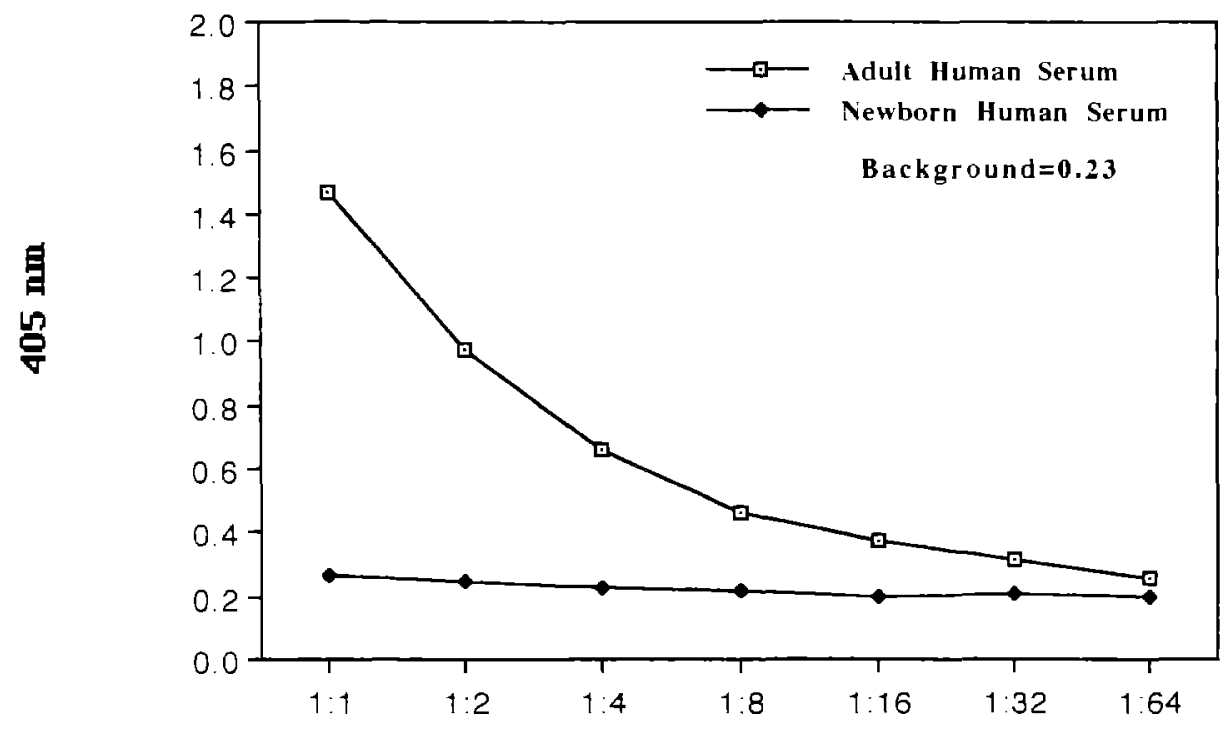

Dilution of Serum

Fig. 5. Binding of human natural IgM xenoantibody to cultured pig aortic ECs was measured by ELISA. Unlike adult human serum, neonatal human serum contains extremely low levels of natural antipig IgM xenoantibodies bound to cultured pig ECs (background 0.2). 


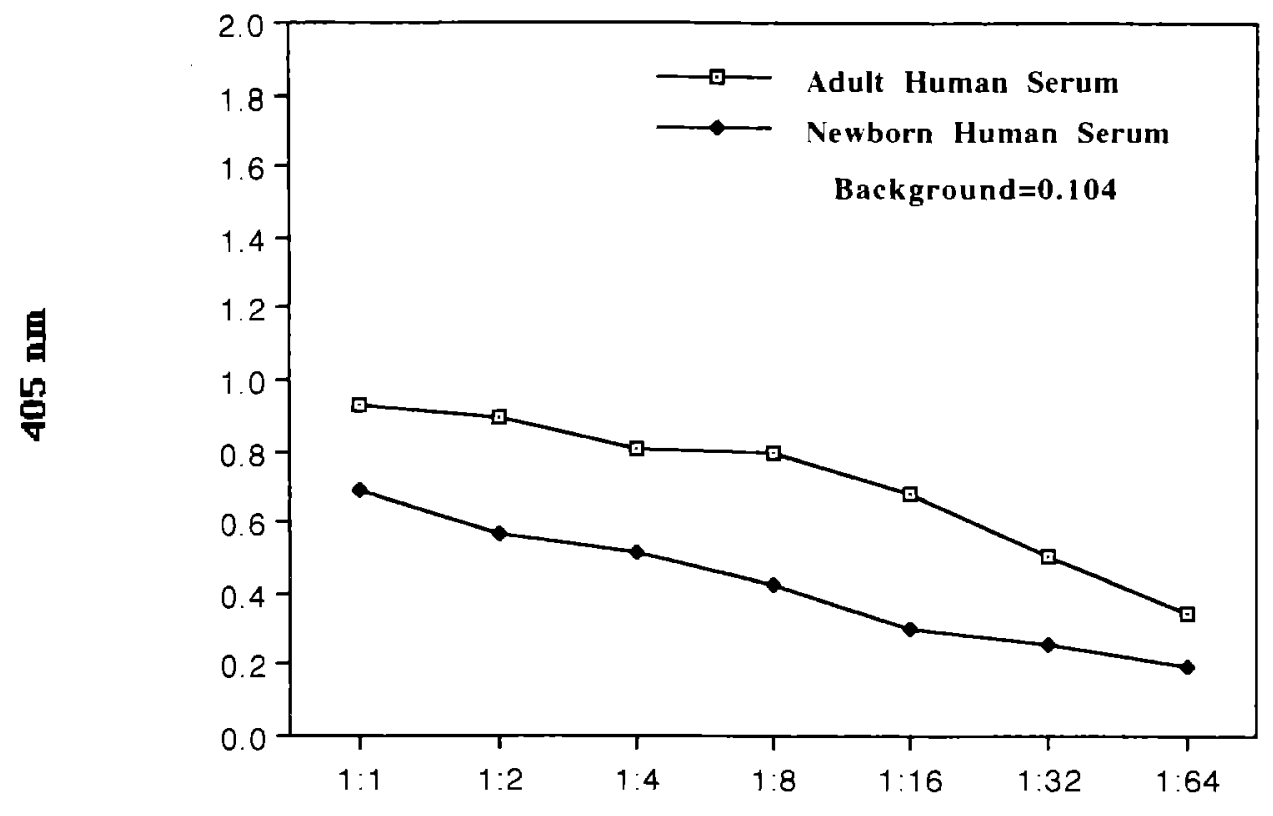

Dilution Of Serum

Fig. 6. The binding of human natural antipig IgG xenoantibodies to cultured pig ECs was determined by EIISA (background 0.104).

Serially diluted samples of both neonatal and adult human serum were then added to plates containing fixed cultured pig aortic EC monolayers. The incubation was carried out at $40^{\circ} \mathrm{C}$ for 60 minutes, and the pig ECs were then washed three times with cold PBS. A secondary antibody (goat antihuman immunoglobulin $\mathrm{M}$ [IgM] or immunoglobulin G [IgG; Organon Teknika Corp., Durham, N.C.]) conjugated with alkaline phosphatase was then added to the plates. Samples were incubated at room temperature for 60 minutes, rewashed three times with PBS, and developed for 30 minutes in the dark with 1 $\mathrm{mg} / \mathrm{ml} P$-nitrophenyl phosphate and $100 \mathrm{mmol} / \mathrm{L}$ diethanolamine in $0.5 \mathrm{mmol} / \mathrm{L}$ magnesium chloride (Sigma). The optical density was measured at $405 \mathrm{~nm}$ with an ELISA reader. A $1 \%$ bovine serum albumin solution was used as a negative control.

MTT assay. The cytotoxicity of both adult and neonatal human sera to pig aortic ECs was measured with the MTT assay (3-(4,5-dimethylthiazoyl-2-y) 2,5 diphenyl-tetrazolium bromide; Sigma) described by Mosmann. ${ }^{16}$ Instead of measuring dead cells with chromium 51-release assay, the tetrazolium salt MTT assay was used to measure the activity of living cells by means of mitochondrial dehydrogenase activity (mitochondrial dehydrogenases of viable cells cleave the tetrazolium ring). Cultured pig aortic ECs were transferred into flat-bottom 96-well tissue culture plates and grown to confluence. The cell monolayers were incubated with $50 \mu \mathrm{l}$ adult or neonatal human serum samples and $50 \mu \mathrm{l}$ rabbit complement (Gentak, Plymouth Meeting, Pa.) at $37^{\circ} \mathrm{C}$ for 4 hours. The cells were gently washed twice with Hank's medium (Life Technologies) and then with stock MTT solution $(10 \mu 1$ per $100 \mu 1$ medium), and EC culture medium was added to each well (total volume $100 \mu \mathrm{l} /$ well). The plates were incubated at $37^{\circ} \mathrm{C}$ for 4 hours. After the final incubation, the MTT solution was removed and $100 \mu$ l of acid-isopropanol (Sigma) was added to each well to dissolve the purple MTT formazan crystals. The plates were measured with multiwell scanning spectrophotometers (ELISA readers) at $595 \mathrm{~nm}$. Pig EC culture medium (10\% fetal calf serum in Dulbecco's modified Eagle medium) was used as negative control. Rabbit antithymocyte globulin was used as positive control. Rabbit antithymocyte globulin produced $100 \%$ cytotoxicity to pig ECs (trypan blue dye exclusion), and this was compared with $100 \%$ cell lysis caused by cell lysis buffer (Fisher Scientific Co., Orangeburg, N.Y.).

Percentage viability of pig ECs was calculated as follows: Percentage of viability $=100 \% \times($ Measured sample - Positive control)/(Negative control - Positive control).

Statistical methods. Student's $t$ test was used to analyze paired data.

\section{Results}

Proliferative response of human PBLs to pig ECs. In this in vitro study, we initially assessed the kinetics of the adult human cell-mediated immune reaction to pig $\mathrm{EC}$ membrane antigens in a one-way xMLER. We demonstrated that the cultured pig aortic ECs strongly stimulated human PBLs as antigen-presenting cells. The kinetics of the cellular reaction from adult human subjects 1 and 2 , as 


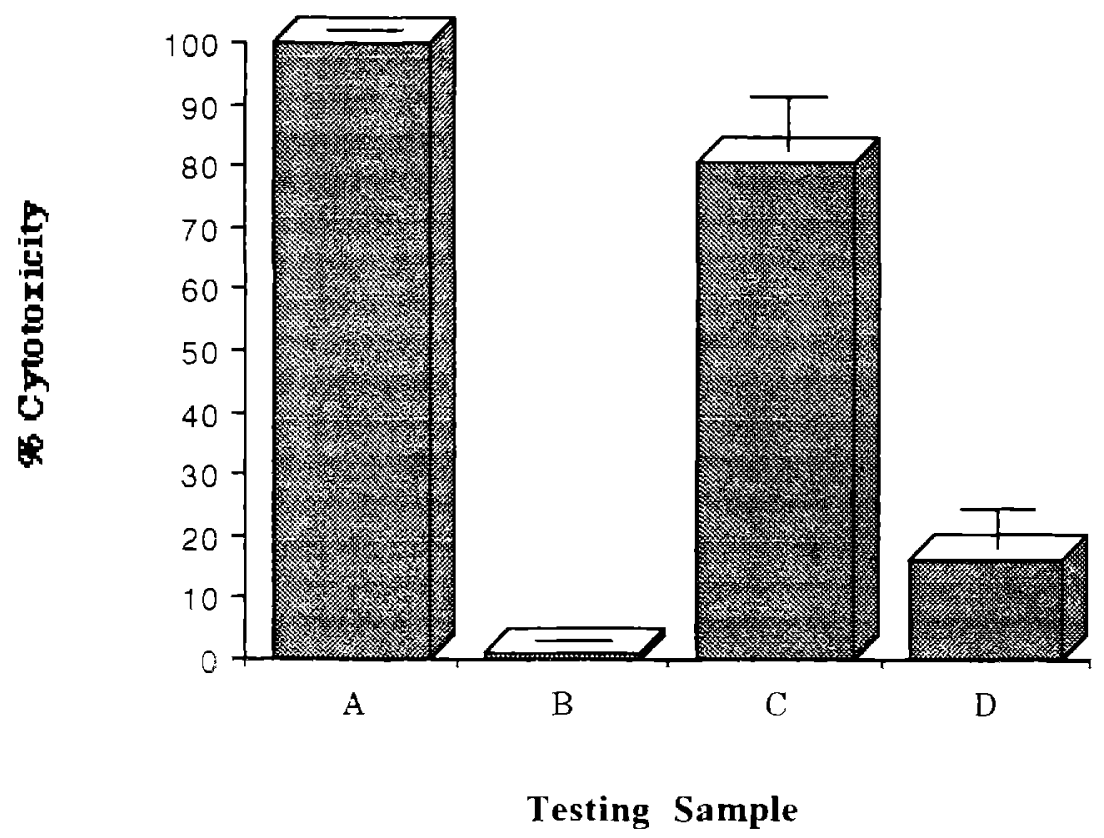

Fig. 7. Viability of cultured pig aortic ECs after incubation with adult or neonatal human serum and rabbit complement was measured by MTT assay in antithymocyte globulin $(A)$, culture medium $(B)$, adult human serum $(C)$, and neonatal human serum $(D)$. Neonatal human serum demonstrates extremely low levels of cytotoxicity, in contrast to extremely high levels of cytotoxicity observed with adult human serum.

shown in Fig. 1, demonstrate that proliferative immune response is a function of the number of responder cells. An extremely high proliferative level was noted at $2 \times 10^{5}$ responder cells/well. As shown in Fig. 2, adult human PBLs from all subjects tested showed extremely high levels of proliferation in response to cultured pig aortic ECs $\left(2 \times 10^{5}\right.$ cells/well).

Proliferation of neonatal human PBLs to cultured pig aortic ECs. The proliferation of neonatal human PBLs $\left(2 \times 10^{5}\right.$ cells/well $)$ to cultured pig aortic ECs was examined with xMLER. The results demonstrated that, like adult human PBLs, neonatal human PBLs recognize and proliferate in response to cultured pig ECs (Fig. 3); however, the proliferative responses of these neonatal human PBLs were significantly lower than those of adult human PBLs (Fig. 4).

Neonatal human serum lacks natural xenoreactive antibodies. Cellular ELISA with adult human serum samples demonstrated high binding levels of natural antipig IgM xenoantibodies to cultured pig EC monolayers. The binding of natural IgG antibodies to cultured pig ECs was also noted in adult human serum samples. Similar binding affinities were observed for IgM and IgG antibodies to pig ECs.

In contrast to adult human serum, neonatal human serum demonstrated extremely low binding levels of natural $\mathrm{IgM}$ xenoantibodies to cultured pig ECs (Fig. 5). The binding of neonatal human IgG antibodies to pig ECs was lower than that in adult serum (Fig. 6).

Cytotoxicity by MTT assay. Pooled adult human sera demonstrated an extremely high degree of cytotoxicity to pig ECs in the presence of rabbit complement. In contrast, pooled neonatal human sera demonstrated only minimal cytotoxicity to cultured pig ECs (Fig. 7). Incubation of rabbit complement and culture medium with cultured pig ECs did not result in cytotoxicity, as determined by trypan blue dye exclusion.

Neonatal pig aortic ECs express xenoantigens. As shown in Fig. 8, the binding of adult human natural IgM xenoantibodies to neonatal pig aortic ECs was similar to that observed with adult pig ECs.

\section{Discussion}

Hyperacute rejection remains the major barrier to the use of distantly related xenografts in clinical 


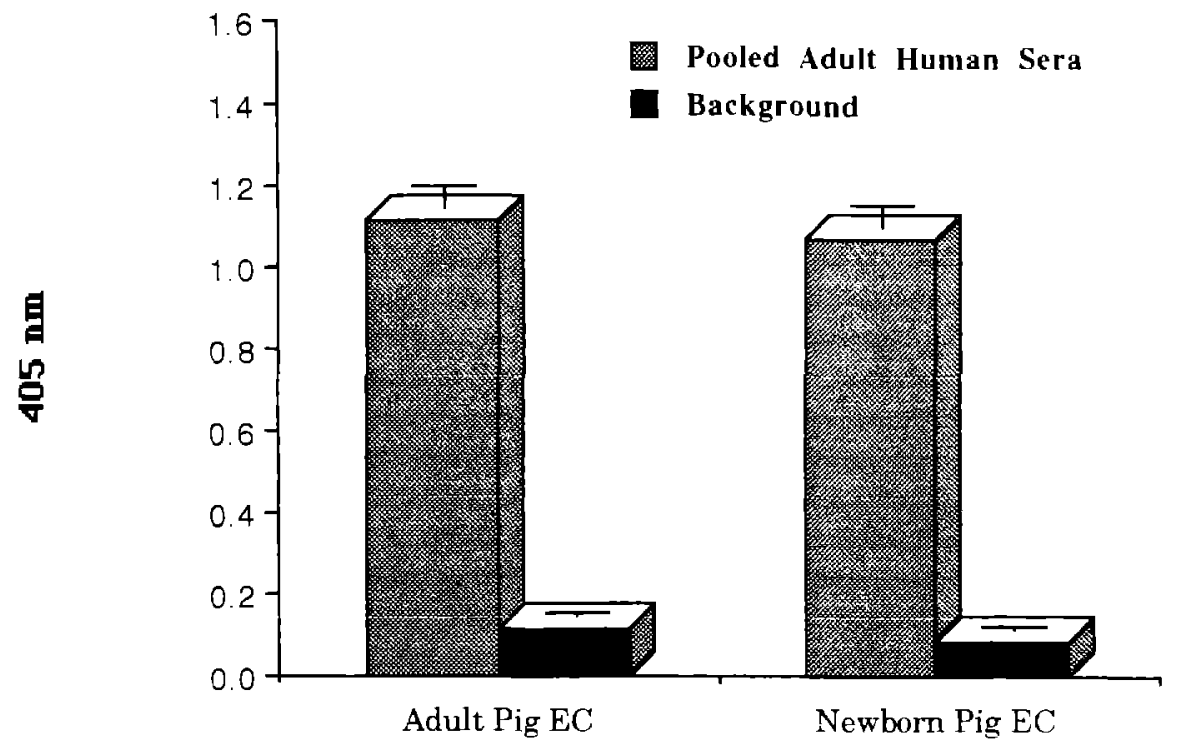

Target Cell

Fig. 8. Binding of adult human natural IgM xenoantibodies to cultured neonatal and adult pig aortic ECs, as measured by ELISA.

transplantation. The hyperacute rejection reaction is dependent on the binding of natural xenoreactive antibody to vascular EC xenoantigens, followed by the activation of complement. ${ }^{6,17,18} \mathrm{IgM}$, immunoglobulin $\mathrm{A}$, and immunoglobulin $\mathrm{D},{ }^{19,20}$ in contrast to $\mathrm{IgG}$, are unable to cross the placental barrier because of their large size (the molecular weight of IgM is approximately 900,000 daltons). We therefore reasoned that because natural antipig $\operatorname{IgM}$ xenoantibodies are either absent or present at extremely low levels in neonatal human serum, cellular immune responses may actively participate in the rejection of pig-to-human xenografts. This hypothesis is supported by our finding that cultured pig aortic ECs are potent stimulators of human PBLs. Of interest is the observation that the lymphocyte proliferative response of human neonates is significantly lower than that of human adults. This observation can be explained in part by studies showing that human cord blood contains a relatively large number of suppressor $\mathrm{CD} 4+\mathrm{T}$ cells. ${ }^{21-23} \mathrm{In}$ addition, cell-mediated cytotoxicity has been shown to be deficient in the human neonate. ${ }^{24-26}$ On the basis of these findings and our in vitro proliferative results, it appears that the immune systems of human neonates may be more readily manipulated than those of human adults to accept pig xenografts.

Neonatal human humoral immunity directed against distantly related xenografts, such as those from the pig, have not been previously studied. We have now demonstrated that neonatal human serum contains extremely low levels of IgM compared with the serum of human adults. In addition, these data show a high binding level of IgG antibodies to pig ECs in the adult, in contrast to a relatively lower binding level of IgG antibodies seen with neonatal human serum. This finding is consistent with Wang's observation ${ }^{27}$ of selective placental transfer of IgG2 antibody subclass to the fetus. The functional significance of this finding in the human neonate, however, remains unclear.

Adult human serum produced extremely high levels of cytotoxicity to cultured pig ECs, as determined by MTT assay. This finding correlates with high binding levels of natural IgM antibodies to pig ECs. In contrast, neonatal human serum produced low cytotoxicity to cultured pig ECs, which correlated with low binding levels of natural IgM xenoantibodies. These findings suggest that human natural antipig cytotoxic xenoantibodies are primarily IgM in nature and that xenograft rejection in human neonates (in whom $\operatorname{IgM}$ is very low or absent) is probably not entirely dependent on humoral immunity. This interpretation is supported by previous data from our laboratory, which demonstrate that human and baboon IgG antibodies bind to cultured 
pig ECs and lymphocytes without cell lysis. ${ }^{18,28}$ This natural model of antipig IgM xenoantibody depletion may therefore prevent hyperacute rejection of xenografts from pig to human neonates. It is important to note that the question of whether cultured neonatal pig ECs express xenoantigens on their cell membranes is incompletely resolved. In addressing this question, we showed by ELISA that human antipig xenoreactive antibodies recognize both adult pig ECs and neonatal pig ECs. The binding levels of natural IgM xenoantibodies to both cell lines were similar, suggesting that aortic ECs of the neonatal pig, like those of the adult pig, do express xenoantigens on their cell membranes.

The fact that neonatal baboon serum, like neonatal human serum, contains extremely low levels of natural antipig cytotoxic IgM xenoantibodies led us to transplant neonatal pig hearts heterotopically into the necks of neonatal baboon recipients. Histologic examinations of the functioning grafts excised at $15,81,82,82$, and 87 hours after transplantation demonstrated normal myocardium without evidence of hyperacute rejection. Immunohistochemical studies established no deposition of $\operatorname{IgM}$ or IgG xenoantibody, C3, C4, or $\mathrm{C} 5 \mathrm{~b}$ on the $\mathrm{EC}$ surface of the xenografts, although there was focal deposition of platelets and fibrin. Serum samples collected from recipients before and after transplantation revealed normal levels of serum complement. ${ }^{29-31}$ These results further strengthen our hypothesis that pig-to-neonatal human xenotransplantation may eventually be feasible.

The application of heart transplantation to human neonatal infants is still limited by the severe shortage of donor organs. Xenografts may provide one solution to this problem, but only if hyperacute rejection can be overcome. This study provides preliminary insight into the humoral and cellular immune phenomena seen with xenografts from pigs to newborn human beings.

\section{REFERENCES}

1. Michler RE, Rose EA. Pediatric heart and heart-lung transplantation. Ann Thorac Surg 1991;53:708-9.

2. McManus RP, O'Hair DP, Beitzinger JM, et al. Patients who die awaiting heart transplantation. J Heart Lung Transplant 1993;12:159-72.

3. Bravery CA, Hunt BJ, Thorpe SJ, Yacoub M. Expression of ABH antigens in porcine heart tissue. Transplant Proc 1992;24:445-6.

4. Lexer G, Cooper DK, Rose AG, et al. Hyperacute rejection in a discordant (pig to baboon) cardiac xenograft model. J Heart Transplant 1986;5:411-7.

5. Lexer G, Cooper DK, Wicomb WN, et al. Cardiac transplan- tation using discordant xenografts in a nonhuman primate model. Transplant Proc 1987;19(1 Pt 2):1153-4.

6. Platt JL, Fischel RJ, Matas AJ, Reif SA, Bolman RM, Bach FH. Immunopathology of hyperacute xenograft rejection in a swine-to-primate model. Transplantation 1991;52:214-20.

7. Cattell V, Jamieson SW. Hyperacute rejection of guinea-pig to rat cardiac xenograft. I. Morphology. J Pathol 1974;115: 183-9.

8. Rose AG, Cooper DK, Human PA, Reichenspurner $\mathrm{H}$, Reichart B. Histopathology of hyperacute rejection of the heart: experimental and clinical observations in allografts and xenografts. J Heart Lung Transplant 1991;10:223-34.

9. DeBault L, Ye Y, Rolf LL, et al. Ultrastructural features in hyperacute rejected baboon cardiac allografts and pig cardiac xenografts. Transplant Proc 1992;24:612-3.

10. Cooper DK, Human PA, Lexer G, et al. Effects of cyclosporine and antibody adsorption on pig cardiac xenograft survival in the baboon. J Heart Transplant 1988;7:238-45.

11. Reding R, Davies HS, White DJ, et al. Effect of plasma exchange on guinea pig-to-rat heart xenografts. Transplant Proc 1989;21:534-6.

12. Fischel RJ, Platt JL, Matas AJ, et al. Prolonged survival of a discordant cardiac xenograft in a rhesus monkey. Transplant Proc 1991;23:589-590.

13. Leventhal JR, Dalmasso AP, Cromwell JW. Prolongation of cardiac xenograft survival by depletion of complement. Transplantation 1993;55:857-66.

14. Rosiers $\mathrm{CD}$, Nees S, Gerlach E. Purine metabolism in cultured aortic and coronary endothelial cells. Biochem Cell Biol 1989;67:8-15.

15. Platt JL, Turman MA, Noreen HJ, Fischel RJ, Bolman RM, Bach FH. An ELISA assay for xenoreactive natural antibodies. Transplantation 1990;49:1000-1.

16. Mosmann T. Rapid colorimetric assay for cellular growth and survival: application to proliferation and cytotoxicity assays. $J$ Immunol Methods 1983;65:55-63.

17. Platt JL, Vercellotti GM, Dalmasso AP, et al. Transplantation of discordant xenografts: a review of progress. Immunol Today 1990;11:450-8.

18. Xu H, Edwards $\mathrm{N}$, Chen $\mathrm{JM}$, et al. Identification and functional analysis of human natural anti-pig xenoantibodies. Transplant Proc 1994;26:1365-9.

19. Stiehm EH, Fudenberg HH. Serum levels of immune globulins in health and disease: a survey. Pediatrics 1966;37:715-27.

20. Leslie GA, Swate TE. Structure and biologic functions of human IgD. I. The presence of immunoglobulin D in human cord sera. J Immunol 1972;109:47-50.

21. Hayward AR, Lawton AR. Induction of plasma cell differentiation of human fetal lymphocytes: evidence for functional immaturity of T and B cells. J Immunol 1977;119:1213-7.

22. Thomas RM, Linch DC. Identification of lymphocyte subsets in the newborn using a variety of monoclonal antibodies. Arch Dis Pediatr Adolesc Med 1983;58:34-41.

23. Jacoby DR, Oldstone MB. Delineation of suppressor and helper activity within the OKT4-defined T lymphocyte subset in human newborns. J Immunol 1983;131:1765-70.

24. Campbell AC, Waller C, Wood J. Lymphocyte subpopulations in the blood of newborn infants. Clin Exper Immunol 1974;18:469-82.

25. Andersson T, Stejskal V, Harfast B. An in vitro method for study of human lymphocyte cytotoxicity against mumps virus infected target cells. J Immunol 1975;114(1 Pt 2):237-43. 
26. Toivanan P, Granberg C, Manninen K. Cell-mediated lympholysis by human neonatal lymphocytes. In: Lucas DO, ed. Regulatory mechanisms in lymphocyte activation. New York: Academic Press, 1977;638-40.

27. Wang AC, Faulk WP, Stuckey MA, Fundenberg HH. Chemical differences of adult, fetal and hypogammaglobulinemic IgG immunoglobulins, Immunochemistry 1970;7:703-8.

28. Xu H, Kwiatkowski P, Chen JM, et al. Abrogation of baboon natural xenoantibodies by DL-penicillamine. Transplantation 1994;58:1299-303.
29. Xu H, Edwards NM, Chen JM, Kwiatkowski P, Rosenberg S, Michler RE. Newborn baboon serum lacks natural anti-pig xenoantibody. Transplantation 1995;59:1189-94.

30. Kaplon RJ, Platt JL, Xu H, Kwiatkowski PA, Edwards NM, Michler RE. Prolonged survival of pig cardiac xenografts in unmodified newborn baboons. Transplant Proc 1994;26:1072.

31. Kaplon RJ, Michler RE, Xu H, Kwiatkowski PA, Edwards NM, Platt JL. Absence of hyperacute rejection in newborn pig-to-baboon cardiac xenografts. Transplantation 1995;59: $1-6$.

\section{Bound volumes available to subscribers}

Bound volumes of The Journal of Thoracic and Cardiovascular Surgery are available to subscribers (only) for the 1996 issues from the Publisher, at a cost of $\$ 100.50$ for domestic, $\$ 128.94$ for Canadian, and $\$ 120.50$ for international subscribers for Vol. 111 (January-June) and Vol. 112 (July-December). Shipping charges are included. Each bound volume contains a subject and author index and all advertising is removed. Copies are shipped within 60 days after publication of the last issue of the volume. The binding is durable buckram with the JournaL name, volume number, and year stamped in gold on the spine. Payment must accompany all orders. Contact Mosby-Year Book, Inc., Subscription Services, 11830 Westline Industrial Drive, St. Louis, Missouri 63146-3318, USA; phone $800-453-4351$ or 314-453-4351.

Subscriptions must be in force to qualify. Bound volumes are not available in place of a regular JourNaL subscription. 